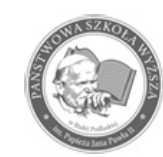

ISSN 2083-3725
Authors' contribution/

Wkład autorów:

A. Zaplanowanie badań/

Study design

B. Zebranie danych/

Data collection

C. Analiza statystyczna/

Statistical analysis

D. Interpretacja danych/

Data interpretation

E. Przygotowanie tekstu/

Manuscript preparation

F. Opracowanie

piśmiennictwa/

Literature search

G. Pozyskanie funduszy/

Funds collection

\section{TERRITORIAL MARKETING AS A METHOD OF CREATING NEW VALUES OF A TERRITORIAL UNIT BASED ON THE EXAMPLE OF DOBRA SZCZECIŃSKA MUNICIPALITY IN THE WEST POMERANIAN PROVINCE}

\section{MARKETING TERYTORIALNY JAKO SPOSÓB NA WYKREOWANIE NOWYCH WARTOŚCI JEDNOSTKI TERYTORIALNEJ NA PRZYKŁADZIE GMINY DOBRA SZCZECIŃSKA W WOJEWÓDZTWIE ZACHODNIOPOMORSKIM}

\author{
Jolanta Kondratowicz-Pozorska ${ }^{1(\mathrm{~A}, \mathrm{~B}, \mathrm{~B}, \mathrm{D}, \mathrm{E}, \mathrm{F}, \mathrm{G}, \mathrm{f})}$
}

\author{
${ }^{1}$ The Koszalin University of Technology, Faculty of Economic Sciences \\ Politechnika Koszalińska, Wydział Nauk Ekonomicznych
}

Kondratowicz-Pozorska J. (2018), Territorial marketing as a method of creating new values of a territorial unit based on the example of Dobra Szczecińska municipality in the West Pomeranian Province/ Marketing terytorialny jako sposób na wykreowanie nowych wartości jednostki terytorialnej na przykładzie gminy Dobra Szczecińska w województwie zachodniopomorskim. Economic and Regional Studies, Vol. 11, No. 1, pp. 118- 131. https://doi.org/10.29316/ers-seir.2018.09

\section{Summary}

\section{ORIGINAL ARTICLE}

JEL code: M31, M39, Q1, Q001, R58, R1

Submitted:

October 2017

Accepted:

March 2018

Tables: 1

Figures: 3

References: 22

\section{ORYGINALNY ARTYKUŁ} NAUKOWY

Klasyfikacja JEL: M31, M39, Q1, Q001, R58, R1

Zgłoszony:

Październik 2017

Zaakceptowany:

Marzec 2018

Tabele: 1

Rysunki: 3

Literatura: 22
Subject and purpose of work: The subject of the study is to show that the method of managing a municipality, taking into account the marketing philosophy, creates additional values for a given municipality. The purpose of the work is to show that Dobra Szczecińska Municipality, being a territorial unit, has developed a certain manner of managing and directing local resources, which, using territorial marketing, has created a unique and inimitable character of the location. Materials and methods: Scientific literature, source materials from the Municipal Office of Dobra Szczecińska as well as all statistics and studies available online were used. Literature review and analysis, as well as deductive and inductive methods were applied as research tools. Results: It has been proved that Dobra Szczecińska is a municipality with its own identity, possesses its own unique image, cares about the municipality's product and satisfies the needs of its residents and entrepreneurs. Conclusions: The municipality was justifiably ranked 23rd in the 2016 Ranking, because the local authorities make every effort to ensure that the residents and entrepreneurs believe that they live and operate in the best place in West Pomeranian Province. The analysis of the collected material confirmed that Dobra Szczecińska municipality is rightly called a good one because it develops in accordance with the principles of sustainable development.

Keywords: territorial marketing, Szczecin Dobra, sustainable development, added value

\section{Streszczenie}

Przedmiot i cele pracy: Przedmiotem opracowania jest wykazanie, że sposób zarządzania gminą uwzględniający filozofię marketingu powoduje tworzenie dodatkowych wartości dla gminy. Celem pracy jest ukazanie, że jednostka terytorialna jaką jest gmina Dobra Szczecińska wykształciła pewien sposób zarządzania i kierowania zasobami lokalnymi, który wykorzystując marketing terytorialny wykreował unikalny i niepowtarzalny charakter miejsca. Materiały i metody: Wykorzystano literaturę naukową, materiały źródłowe z Urzędu Gminy Dobra Szczecińska oraz wszystkie dane statystyczne i opracowania dostępne $\mathrm{w}$ internecie. Jako metody badawcze zastosowano przegląd $\mathrm{i}$ analize literatury, metody dedukcyjne i indukcyjne. Wyniki: Dowiedziono, że gmina Dobra Szczecińska jest gminą o własnej tożsamości, ma własny niepowtarzalny wizerunek, dba również o produkt gminny oraz zaspokaja potrzeby swoich mieszkańców i przedsiębiorców. Wnioski: Gmina słusznie została wpisana na 23 miejsce w Rankingu 2016, ponieważ władze terenu dokładają wszelkich starań, aby mieszkańcy i przedsiębiorcy uważali, że mieszkają i działają w najlepszym miejscu w województwie zachodniopomorskim. Analiza zebranego materiału potwierdziła, że gm. Dobra Szczecińska słusznie nazywana jest dobrą, bowiem rozwija się zgodnie z zasadami zrównoważonego rozwoju.

Słowa kluczowe: marketing terytorialny, Dobra Szczecińska, rozwój zrównoważony, wartości dodana

Address for correspondence/ Adres korespondencyjny: $d r$ hab. Jolanta Kondratowicz-Pozorska, prof. PK, (ORCID 0000-0001-6467-8142), Politechnika Koszalińska, Wydział Nauk Ekonomicznych, ul. Kwiatkowskiego 6E, 75-343 Koszalin, Polska; tel. +48 94 343-91-37; e-mail: jolanta.pozorska@tu.koszalin.pl

Journal indexed in/ Czasopismo indeksowane w: AgEcon Search, AGRO, BazEkon, Index Copernicus Journal Master List, ICV 2016: 92,91; Polish Ministry of Science and Higher Education 2016: 9 points/ AgEcon Search, AGRO, BazEkon, Index Copernicus Journal Master List ICV 2016: 92.91; Ministerstwie Nauki i Szkolnictwa Wyższego 2016: 9 punktów. Copyright: (C) 2018 Pope John Paul II State School of Higher Education in Biała Podlaska, Marek Kuźmicki. All articles are distributed under the terms of the Creative Commons Attribution-NonCommercial-ShareAlike 4.0 International (CC BY-NC-SA 4.0) License (http://creativecommons.org/licenses/by-nc-sa/4.0/), allowing third parties to copy and redistribute the material in any medium or format and to remix, transform, and build upon the material, provided the original work is properly cited and states its license. 


\section{Introduction}

In Poland, territorial marketing entered discussions in the early 90s of the previous century. The precursors in the development of the marketing concept for the functioning of municipalities in Poland were A. Szromnik, R. Domański, T. Markowski, J. Komorowski and J. Marak ${ }^{1}$. (Sekuła 2005, p. 219). Currently, in the domestic literature, the marketing approach used in territorial units may be called: urban, municipal, territorial, urban, communal, regional, spatial or place marketing. In Englishlanguage literature, it is primarily called place marketing or city marketing, sometimes territorial marketing, while in German-speaking literature, the most common one is the concept of communal marketing (kommunales marketing territorial), just as in Italian literature (marketing territoriale) (Florek 2013, p. 15). Over time, the group dealing with the issue of territorial marketing in Poland and abroad is constantly expanding, and the number of publications is becoming increasingly substantial. Despite this, one, recognized by all, definition of territorial marketing, has still not been developed, and its essence, goals, basic forms and reference groups are not always appropriately understood (Szromnik 2012, p. 27).

For the purposes of this paper, it was assumed, following E. Chrzan, that territorial marketing is actually the management of a certain territorial unit with the use of marketing philosophy, which leads to satisfying the needs and desires of residents and entrepreneurs operating therein. Thus, it leads to the improvement of material conditions of life as well as the spiritual development of the local community (Chrzan 2015, p. 110). Territorial marketing - as the name suggests - refers to a specific place, which may be a region, area, city, municipality, district or other local units, and has three groups of objectives to fulfill (Chrzan 2015, p.112):

1. ones relating to the improvement of living conditions and business activity for the inhabitants of a territorial unit - development and strengthening of services provided by public institutions, the use of which is difficult for residents and business entities;

2. ones related to increasing the attractiveness and position of a given territorial unit in the competition for attracting investors, tourists, elite representatives, etc.;

3. ones related to shaping a positive image and increasing the competitiveness of a region as a whole, as well as of its products, compared to other regions and their products on the global market.

K. Moeller and A. Rajala stated that one of the characteristics of the value creation system is the

${ }^{1}$ For example: Komorowski J. (1993), Marketing miejski i jego znaczenie we współczesnym rozwoju miasta. Zeszyty Naukowe AE in Poznań, Prace z zakresu gospodarki przestrzennej, ser. I, nr 206, pp. 44-55 and Marak J. (1994), Marketingowa strategia rozwoju gminy - koncepcja metodologiczna. In: J. Marak (ed.) Zachowania podmiotów sfery konsumpcji (gospodarstw domowych samorzadów terytorialnych, przedsiębiorstwi instytucji). Akademia Ekonomiczna w Katowicach, Katowice, pp. 169-171.

\section{Wstęp}

W Polsce o marketingu terytorialnym zaczęto dyskutować we wczesnych latach 90. ub. wieku. Prekursorami rozwoju marketingowej koncepcji funkcjonowania gmin na gruncie polskim byli A. Szromnik, R. Domański, T. Markowski, J. Komorowski i J. Marak ${ }^{1}$ (Sekuła 2005, s. 219). Obecnie w literaturze krajowej podejście marketingowe wykorzystane $w$ jednostkach terytorialnych może być nazywane marketingiem: miejskim, komunalnym, terytorialnym, urbanistycznym, gminnym, regionalnym, przestrzennym lub też marketingiem miejsc. W literaturze anglojęzycznej nazywany jest przede wszystkim marketingiem miejsc (place marketing) lub miast (city marketing), niekiedy terytorialnym (territorial marketing), podczas gdy w literaturze niemieckojęzycznej najczęściej spotyka się pojęcie marketingu komunalnego (kommunales marketing territorial), podobnie jak we włoskiej (marketing territoriale) (Florek 2013, s. 15). W miarę upływu czasu grono zajmujących się zagadnieniem marketingu terytorialnego zarówno w Polsce jak i za granicą stale się poszerza, a liczba publikacji staje się liczniejsza. Pomimo tego nadal nie wypracowano jednej uznawanej przez wszystkich definicji marketingu terytorialnego oraz nie zawsze właściwie rozumie się jego istotę, cele oraz podstawowe formy i grupy odniesienia (Szromnik 2012, s. 27).

Dla celów niniejszej pracy przyjęto za E. Chrzan, że marketing terytorialny to właściwie zarządzanie pewną jednostką terytorialną $\mathrm{z}$ wykorzystaniem filozofii marketingu, które prowadzi do zaspokojenia potrzeb i pragnień mieszkańców oraz działających tam przedsiębiorców. Prowadzi więc do poprawy tak materialnych warunków życia, jak i rozwoju duchowego lokalnej społeczności (Chrzan 2015, s. 110). Marketing terytorialny - jak sama nazwa wskazuje - dotyczy konkretnego miejsca, którym może być region, rejon, miasto, gmina, powiat lub inne jednostki lokalne, i ma do spełnienia trzy grupy celów (Chrzan 2015, s.112):

1. odnoszące się do polepszenia warunków życia i prowadzenia działalności gospodarczej dla mieszkańców jednostki terytorialnej - rozwijanie i umacnianie usług świadczonych przez instytucje publiczne, z których korzystanie jest utrudnione dla mieszkańców oraz podmiotów gospodarczych;

2. związane $\mathrm{z}$ podnoszeniem atrakcyjności oraz pozycji danej jednostki terytorialnej we współzawodnictwie o przyciąganie inwestorów, turystów, przedstawicieli elit itd.;

3. związane z kształtowaniem pozytywnego wizerunku oraz podnoszeniem konkurencyjności regionu jako całości, jak i jego produktów, na tle innych regionów i ich produktów na rynku globalnym.

\footnotetext{
Na przykład: Komorowski J. (1993), Marketing miejski i jego znaczenie we wspótczesnym rozwoju miasta. Zeszyty Naukowe AE w Poznaniu, Prace z zakresu gospodarki przestrzennej, ser. I, nr 206, s. 44-55 oraz Marak J. (1994), Marketingowa strategia rozwoju gminy - koncepcja metodologiczna. W: J. Marak (red.) Zachowania podmiotów sfery konsumpcji (gospodarstw domowych, samorząów terytorialnych, przedsiębiorstw i instytucji). Akademia Ekonomiczna w Katowicach, Katowice, s. 169-171.
} 
determination, in other words the knowledge, of how well entity resources are known and used to create and take advantage of all opportunities (K. Moeller, A. Rajala 2007, p. 898). A. Kożuch believes that local governments have all the tools to implement local development, such as creating development strategies, arranging spatial development, issuing localisation decisions and permits to use environmental resources and introduce changes thereto. Local governments balance the social and ecological dimension by supporting education and health protection, as well as the economic dimension by stimulating and stimulating positive development directions (Kożuch 2011, p. 19). Therefore, they are units ready to create new values through the systematic implementation of everyday activities. With the above-mentioned understanding of territorial marketing and its objectives, the author conducted a detailed analysis of all documents, activities and efforts of the authorities of Dobra Szczecińska municipality in West Pomeranian Province carried out since 2004 for the benefit of this territory, in order to enable the municipality to use its resources better and create conditions conducive to creating and obtaining increasingly high value.

The aim of this study is to show that the territorial unit of Dobra Szczecińska has developed a certain way of managing and directing local resources, which enables it to create a product that satisfies the local community. In other words, the municipality, through territorial marketing, has created a unique and inimitable character of the place, and territorial marketing has become a flagship of competitiveness in the background of other units.

\section{Material and research methods}

In order to investigate the subject of the work, literature studies covering domestic and foreign sources were conducted. In addition, for the purposes of the work, numerous documents being in the possession of the employees of the Municipal Office of Dobra Szczecińska were collected and analysed, such as: Statute of Dobra Szczecińska Municipality of 2003, organisational regulations of the Municipal Office of 2010, resolutions and regulations collected since 2003, plans for renovating towns comprised by Dobra Szczecińska Municipality, as well as the environmental protection program, waste management plan and others. In addition, changes in local plans were analysed and compared with the provisions in the Study of conditions and directions for spatial development and the Local Development Strategy or the Integrated Sustainable Mobility Plan for the Szczecin Metropolitan Area for 20162023. Conducting interviews with employees of the Municipal Office was also an important stage of research work, as well as tracing how the marketing activities and participation in international cooperation programs were undertaken and conducted, as well as activities aimed at improving the living conditions of the residents and the business
K. Moeller i A. Rajala stwierdzili, że jedną z charakterystyk systemu kreowania wartości jest determinacja, czyli inaczej mówiąc wiedza jak dobrze są znane i wykorzystywane zasoby podmiotów do tworzenia i wykorzystywania wszystkich możliwości (K. Moeller, A. Rajala 2007, s. 898). A. Kożuch uważa, że samorządy posiadają wszystkie narzędzia realizacji rozwoju lokalnego, jakimi są tworzenie strategii rozwoju, planowanie zagospodarowania przestrzennego, wydawanie decyzji lokalizacyjnych oraz pozwoleń na korzystanie z zasobów środowiska i wprowadzanie w nim zmian. Samorządy równoważą wymiar społeczny i ekologiczny przez wspieranie edukacji i ochrony zdrowia, natomiast wymiar gospodarczy przez pobudzanie i stymulowanie pozytywnych kierunków rozwoju (Kożuch 2011, s. 19). Są zatem jednostkami gotowymi do kreowania nowych wartości poprzez systematyczną realizację codziennych działań. Rozumiejąc w powyższy sposób marketing terytorialny i jego cele przeprowadzono szczegółową analizę wszystkich dokumentów, działań i starań władz gminy Dobra Szczecińska w województwie zachodniopomorskim, które są prowadzone od 2004 roku na rzecz tegoż terytorium, by gmina mogła lepiej wykorzystać swoje zasoby i stworzyć warunki zmierzające do kreowania i otrzymywania coraz większej wartości.

Celem opracowania jest wykazanie, że jednostka terytorialna jaką jest gmina Dobra Szczecińska wykształciła pewien sposób zarządzania i kierowania zasobami lokalnymi, który pozwala jej wykreować produkt zaspokajający zbiorowość lokalną. Inaczej ujmując gmina poprzez marketing terytorialny wykreowała unikalny i niepowtarzalny charakter miejsca, a marketing terytorialny stał się konkurencyjną wizytówką na tle innych jednostek.

\section{Materiał i metody badawcze}

Dla realizacji tematu opracowania przeprowadzono studia literaturowe obejmujące źródła krajowe i zagraniczne. Ponadto dla potrzeb pracy zgromadzono i przeanalizowano liczne dokumenty będące w posiadaniu pracowników Urzędu Gminy Dobra Szczecińska, jak: Statut gm. Dobra Szczecińska z 2003 roku, regulaminy organizacyjne Urzędu Gminy od 2010 roku, uchwały i zarządzenia zebrane od 2003 roku, plany odnowy miejscowości wchodzących w skład gm. Dobra Szczecińska, a także program ochrony środowiska, plan gospodarki odpadami i in.. Dodatkowo przeanalizowano zmiany w planach miejscowych i odniesiono do zapisów w Studium uwarunkowań i kierunków zagospodarowania przestrzennego oraz Strategii rozwoju lokalnego czy Zintegrowanego Planu Zrównoważonej Mobilności dla Szczecińskiego Obszaru Metropolitalnego na lata 2016-2023. Ważnym etapem pracy badawczej było także przeprowadzenie wywiadu z pracownikami Urzędu Gminy, jak również prześledzenie jak podejmowane były i prowadzone działania marketingowe, uczestnictwo w programach współpracy międzynarodowej, a także działań mających na celu poprawę warunków życia mieszkańców i warunków gospodarowania dla przedsiębiorców. Władze lokalne muszą 
conditions for entrepreneurs. Local authorities must also make every effort to ensure that the municipality is competitive and attracts investors.

According to I. Siwa, the effects of local development include i.a. creating new values. These include - in the scale of the local economy - includes: new types of activities (economic, social, administrative, etc.), new jobs, companies and institutions, new products, goods and services satisfying internal and external demand, attractive location offers, high quality of the living environment, availability of various services (Siwa 2006 , p. 25). The methods of induction and deduction were therefore applied in an attempt to answer the question of whether Dobra Szczecińska Municipality has created a new unique value and what this value is.

\section{Research results and discussion}

\section{Short description of Dobra Szczecińska Municipality}

Dobra Szczecińska Municipality is a rural municipality located in the direct vicinity of Szczecin, bordering to the west with Germany. It comprises 17 towns and 12 villages. Its geographically diverse area covers $110.28 \mathrm{~km}^{2}$, of which $25 \%$ is covered by forests.

The studied municipality is a region where human activity is not in conflict with nature, i.e. the beauty of nature does not hinder at conducting business and planning investments. The proof of this is the fact that almost every third of its adult inhabitants runs their own business, and the municipality has the lowest unemployment rate in the entire West Pomeranian Province (Diagnoza sytuacji /Situation Diagnosis/... 2013, pp. 35-36). The possibility of contact with nature and at the same time the immediate vicinity of Szczecin, causes people to willingly choose this territorial unit as a place to live (Table1). In 1995, only 5905 people inhabited the studied area, and in 2016 over 21,000; an almost 359\% increase in the number of inhabitants was recorded. It is worth emphasising that the majority of the inhabitants of the municipality are young people, e.g. in the analysed period, the group of people at a working age makes up 63 to $66 \%$ of the total population (Table1.).

However, the increase in the population size stipulates that the municipality completes a number of different tasks to which it is obliged. Among other things, it is necessary to provide water supply, sewage, gas and energy infrastructure, or classroom space for learning in primary schools.

\section{Undertakings as part of internal and external territorial marketing}

The term internal marketing in a city or region specifies those activities, operations and overall undertakings that stimulate the desired behaviour of residents, their groups, as well as non-profit enterprises and institutions located in a given spatial unit (Szromnik 2011, p. 30-31). Significant changes to the image of the studied municipality took place bowiem dołożyć również wszelkich starań, by gmina była konkurencyjna i przyciągała inwestorów.

Według I. Siwej efektami rozwoju lokalnego jest między innymi kreowanie nowych wartości. Do nich - w skali gospodarki lokalnej - zalicza: nowe rodzaje działalności (gospodarczej, społecznej, administracyjnej itp.), nowe miejsca pracy, firmy i instytucje, nowe produkty, dobra i usługi zaspokajające zapotrzebowanie wewnętrzne, jak i zewnętrzne, atrakcyjne oferty lokalizacyjne, wysoką jakość środowiska życia, dostępność różnorakich usług (Siwa 2006, s. 25). Metodami indukcji i dedukcji próbowano zatem udzielić odpowiedzi na pytanie, czy gm. Dobra Szczecińska wykreowała nową niepowtarzalną wartość i co jest tą wartością.

\section{Wyniki badań i dyskusja}

\section{Krótka charakterystyka gminy Dobra Szczeciń- ska}

Gmina Dobra Szczecińska jest gminą wiejską, położoną w bezpośrednim sąsiedztwie Szczecina oraz graniczy od zachodu z Niemcami. W jej skład wchodzi 17 miejscowości i 12 sołectw. Jej zróżnicowany geograficznie obszar to $110,28 \mathrm{~km}^{2}$, gdzie aż $25 \%$ stanowią lasy.

Badana gmina to rejon, w którym działalność człowieka nie jest w konflikcie z przyrodą, tzn. piękno przyrody nie utrudnia prowadzenia działalności gospodarczej i planowania inwestycji. Dowodem na to jest fakt, że blisko co trzeci jej dorosły mieszkaniec prowadzi własną działalność gospodarczą, a gmina ma najniższy w całym województwie zachodniopomorskim wskaźnik wielkości bezrobocia (Diagnoza sytuacji...2013, s. 35-36). Możliwość obcowania z przyrodą, a jednocześnie bezpośrednie sąsiedztwo Szczecina sprawia, że ludzie chętnie wybierają tą jednostkę jako miejsce do zamieszkania (tab.1). W roku 1995 badany teren zamieszkiwało jedynie 5905 osób, w 2016 ponad 21 tysięcy, odnotowano zatem prawie $359 \%$ wzrost liczby mieszkańców. Warto podkreślić, że w przeważającej większości mieszkańcy gminy to ludzie młodzi, np. w badanym okresie grupa osób w wieku produkcyjnym stanowi od 63 do $66 \%$ ogółu mieszkańców (tab.1.).

Wzrost liczby mieszkańców wiąże się jednak dla gminy z wypełnieniem szeregu różnych zadań, do których jest ona zobligowana. Między innymi konieczne jest zapewnienie infrastruktury wodno-kanalizacyjno-gazowej, energetycznej, czy też miejsc do nauki w szkołach podstawowych.

\section{Przedsięwzięcia $w$ ramach wewnętrznego i ze- wnętrznego marketingu terytorialnego}

Terminem marketing wewnętrzny w mieście czy regionie określa się te czynności, operacje oraz całościowe przedsięwzięcia, które stymulują pożądane zachowania mieszkańców, ich grup, a także przedsiębiorstw i instytucji niekomercyjnych zlokalizowanych w danej jednostce przestrzennej (Szromnik 2011, s. 30-31). Do istotniejszych zmian w wizerun- 
Table 1. Variables that characterize different spheres of socio-economic life in Dobra Szczecinska

Tabela 1. Zmienne charakteryzujące różne sfery życia społeczno-gospodarczego w gm. Dobra Szczecińska

\begin{tabular}{|c|c|c|c|c|c|c|c|c|}
\hline \multirow{2}{*}{$\begin{array}{c}\text { Specification / } \\
\text { Wyszczególnienie }\end{array}$} & \multicolumn{8}{|c|}{ Year / Rok } \\
\hline & 1995 & 2000 & 2005 & 2010 & 2013 & 2014 & 2015 & 2016 \\
\hline $\begin{array}{l}\text { The number of inhabitants [person] / } \\
\text { Liczba mieszkańców [os] }\end{array}$ & 5905 & 8620 & 11892 & 17707 & 19301 & 20144 & 20866 & 21186 \\
\hline $\begin{array}{l}\text { Percentage at working age [\%] / } \\
\text { Odsetek w wieku produkcyjnym [\%] }\end{array}$ & 63 & 65 & 65 & 64 & 64 & 64 & 65 & 66 \\
\hline $\begin{array}{l}\text { Net migration rate per } 1000 \text { inhabitants / } \\
\text { Saldo migracji na } 1000 \text { mieszkańców }\end{array}$ & -2 & 1 & 4 & 13 & 15 & 21 & 30,7 & b.d. \\
\hline $\begin{array}{l}\text { Living area }\left[\mathrm{m}^{2} / \text { person] / }\right. \\
\text { Powierzchnia mieszkań }\left[\mathrm{m}^{2} / \mathrm{os}\right]\end{array}$ & 60 & 62 & 81 & 105 & 128,5 & 132,1 & 132,2 & b.d \\
\hline $\begin{array}{l}\text { Water supply net. [\%] / } \\
\text { Sieć wodociągowa [\%] }\end{array}$ & 45 & 50 & 67 & 85 & 98,2 & 98,2 & 98,2 & 98,2 \\
\hline $\begin{array}{l}\text { Sewage system [\%] / } \\
\text { Sieć kanalizacyjna [\%] }\end{array}$ & 35 & 41 & 46 & 58 & 86,0 & 85,2 & 85,3 & 85,3 \\
\hline $\begin{array}{l}\text { Gas supply net. [\%] / } \\
\text { Sieć gazowa [\%] }\end{array}$ & 50 & 60 & 76 & 82 & 88,8 & 82,7 & 82,8 & 82,8 \\
\hline $\begin{array}{l}\text { Nat. economy entities / } \\
\text { Podmioty gosp. nar. }\end{array}$ & 884 & 1339 & b.d. & 3143 & 3797 & 3959 & 3968 & b.d \\
\hline $\begin{array}{l}\text { Municipality income per inhabitant [PLN] / } \\
\text { Dochody gminy zł/mieszkańca [zł] }\end{array}$ & 2510 & 2820 & 2824 & 3090 & 3265 & 3399 & 3894 & 3629 \\
\hline $\begin{array}{l}\text { Municipality expenditure per inhabitant [PLN] / } \\
\text { Wydatki gminy zł/mieszkańca [zł] }\end{array}$ & 1805 & 1972 & 3005 & 3435 & 3361 & 3225 & 3729 & 3469 \\
\hline $\begin{array}{l}\text { Investment expenditure share in total expendi- } \\
\text { ture [\%] / } \\
\text { Udział wydatków inwestycyjnych w wydatkach } \\
\text { ogółem [\%] }\end{array}$ & 38 & 44 & 50 & 46 & 44 & 31 & 39 & 33,5 \\
\hline $\begin{array}{l}\text { Unemployment rate [\%] / } \\
\text { Wskaźnik bezrobocia [\%] }\end{array}$ & 2,6 & 8,1 & 8 & 5,9 & 6,5 & 4,3 & 3,7 & 3,6 \\
\hline
\end{tabular}

Source: own elaboration about https://www.wup.pl/pl/dla-instytucji/statystyka-badania-i-analiza/bezrobocie-w-gminach, http://www.bip.dobraszczecinska.pl/, http://szczecin.stat.gov.pl/vademecum/vademecum_zachod- niopomorskie portrety _gmin/powiat_policki/gmina_wiejska_dobra_szczecinska.pdf, Ekspertyza_Diagnoza_sytuacji_obszarow_wiejskich.pdf, http:// szczecin.stat.gov.pl/vademecum/vademecum_zachodniopomorskie/portret_obszaru_metropolitalnego/szczecinski_obszar_ metropolitalny.pdf, opracowano na podstawie Bank Danych Lokalnych GUS, www.stat.gov.pl, dostęp: 12 maja 2017r.

Źródło: opracowano na podstawie https://www.wup.pl/pl/dla-instytucji/statystyka-badania-i-analiza/bezrobocie-w-gminach, http://www.bip.dobraszczecinska.pl/, http://szczecin.stat.gov.pl/vademecum/vademecum_zachodniopomorskie/portrety_gmin/powiat_policki/gmina_wiejska_dobra_szczecinska.pdf, Ekspertyza_Diagnoza_sytuacji_obszarow_wiejskich.pdf, http://szczecin.stat.gov.pl/vademecum/vademecum_zachodniopomorskie/portret_obszaru_metropolitalnego/szczecinski_ obszar_metropolitalny.pdf, opracowano na podstawie Bank Danych Lokalnych GUS, www.stat.gov.pl, dostęp: 12 maja 2017r.

in 2004, when the local government authorities developed with the help of residents and specialists the Local DevelopmentStrategy of Dobra Municipality, and in 2010 they adopted the Study of conditions and directions for spatial development. The area of the municipality was then divided into three areas: A, B and C. In area A, detached house (Bezrzecze, Wołczkowo, Mierzyn and Skarbimierzyce) and three-storey construction with low environmental impact production and service activity (Mierzyn and Skarbimierzyce) are to be developed. On the other hand, area B (Dobra, Grzepnica, Sławoszewo, Dołuje, Kościno, Wąwelnica and Lubieszyn), apart from the development of functions from the region $\mathrm{A}$, allows intensive economic activity in designated zones. Area $\mathrm{C}$, covering the areas in the north-western part of the municipality (Solec, Rzędziny, Łęgi, and partly Buk) is predestined for the development of recreational functions and agriculture. It was also recognised that medium and large industrial and service investments would be allowed in the areas of Mierzyn, Dołuj, Wąwelnica and Lubieszyn. Imparting a given ku badanej gminy doszło w 2004 roku, gdy władze samorządowe terenu opracowały przy współudziale mieszkańców i specjalistów Strategię Rozwoju Lokalnego Gminy Dobra, a w 2010 roku uchwaliły Studium uwarunkowań i kierunków zagospodarowania przestrzennego. Podzielono wówczas teren gminy na 3 regiony A, B i C. W rejonie A ma intensywnie rozwijać się budownictwo mieszkaniowe jednorodzinne (Bezrzecze, Wołczkowo, Mierzyn i Skarbimierzyce) oraz budownictwo 3 kondygnacyjne i mało uciążliwa działalność produkcyjno-usługowa (Mierzyn i Skarbimierzyce). Z kolei rejon B (Dobra, Grzepnica, Sławoszewo, Dołuje, Kościno, Wąwelnica i Lubieszyn) oprócz rozwoju funkcji z regionu A pozwala w wydzielonych strefach na intensywną działalność gospodarczą. Rejon C, obejmujący tereny w północno-zachodniej części gminy (Solec, Rzędziny, Łęgi, częściowo Buk) jest predestynowany do rozwoju funkcji rekreacyjnych i rolnictwa. Uznano również, że średnie i duże inwestycje o charakterze przemysłowym i usługowym dopuszczone będą na terenie Mierzyna, Dołuj, Wąwelnicy i Lubieszyna. Nadanie 
characteristic (functional and spatial structure) to individual areas belonging to the municipality allowed for preventing investment and construction chaos, and the adopted spatial order gives the feeling that the established investments will not lose their value and will be permanent.

In order to attract investors and new residents the authorities of Dobra Szczecińska Municipality, made every effort to ensure that the interest in the areas within the municipality was constantly growing. Among other things, over the years 2000-2013, about $40 \%$ of expenditures were investment expenditures, including expenditure on investments affecting the life quality of residents and producers located in this area. The data presented in Table 1 shows that income and expenditure calculated per 1 municipality inhabitant increase along with the increase in the number of inhabitants. In addition, Dobra Szczecińska, in order to attract potential investors, had to invest in utilities and take care of the natural environment. At present, the municipality's area is almost entirely covered by the water-sewage-gas network, also, using EU funds ${ }^{2}$, a sewage treatment plant in Redlica was built along with equalisation tanks and hydrophores in Wołczków and Dobra; they are currently being expanded due to the rapidly growing number of inhabitants. As a result of the efforts made, Dobra Szczecińska Municipality, despite having the status of a village municipality, has definitely changed its character. Until the mid-90's of the last century, agricultural activity prevailed; presently the leading ones are trade and service activities as well as low impact production operations. The municipality authorities also try to attract new investors. As a result of undertaken measures, the growth rate of the national economy entities registered in the municipality is particularly dynamic. If the state as at 1995 is taken as the starting point (884), 3084 new entities appeared in 2015, so it can be said that over 20 years the number of business entities was increased by almost 4.5 times (only between 2014 and 2013 an increase of 162 entities was recorded).

The municipality has also become a favourably habitable location for young, wealthier inhabitants of Szczecin, who also care about the fact that the areas on which they settled have not lose their tourist values. Among others, at the instigation of the residents the communal expenditure scheme for the years 2009-2017 came to include such projects as: construction of bicycle paths in the municipality, development of the lakeside area in Stolec, construction of an inter-municipality animal shelter in Dobra, installation of solar lighting on playgrounds and on selected streets in Dobra Szczecińska municipality, as well as the construction and development of recreational areas in Wąwelnica, Bezrzecze, Wołczków, Mierzyn, construction of "orlik" football pitches and reconstruction of the

\footnotetext{
${ }^{2}$ Municipal authorities of Dobra Szczecińska were granted aid un-
der the Rural Development Program for 2007-2013, axis 3 "Quality of life in rural areas and diversification of the rural economy", measure 321 "Basic services for water management and rura population". Implementation of the investment task entitled "Construction and reconstruction of a sewage treatment plant in the town of Redlica, Dobra Szczecińska municipality was possible under the agreement between the municipality and the local government of West Pomeranian Province in Szczecin.
}

charakteru (struktury funkcjonalno-przestrzennej) poszczególnym terenom należącym do gminy pozwoliło zapobiec chaosowi inwestycyjno-budowlanemu, a przyjęty ład przestrzenny daje poczucie, że powstałe inwestycje nie stracą na wartości i będą trwałe.

Władze gminy Dobra Szczecińska, by pozyskać inwestorów oraz nowych mieszkańców, dołożyły wszelkich starań, aby zainteresowanie terenami $\mathrm{w}$ gminie było stale rosnące. Między innymi w latach 2000-2013 około 40\% wydatków stanowiły wydatki inwestycyjne, w tym wydatki na inwestycje wpływające na komfort życia mieszkańców i ulokowanych na tym terenie producentów. $Z$ danych przedstawionych w tabeli 1 wynika, że dochody i wydatki przeliczone na 1 mieszkańca w gminie rosną wraz ze wzrostem liczby mieszkańców. Ponadto Dobra Szczecińska, aby zainteresować potencjalnych inwestorów musiała zainwestować w uzbrojenie terenów i zadbać o środowisko naturalne. Obecnie teren gminy jest prawie w całości pokryty siecią wodno-kanalizacyjno-gazową, wybudowano również, korzystając ze środków unijnych ${ }^{2}$, oczyszczalnię ścieków w Redlicy, zbiorniki wyrównawcze i hydrofornie w Wołczkowie i Dobrej; aktualnie są one rozbudowywane ze względu na gwałtownie rosnącą liczbę mieszkańców. W wyniku poczynionych zabiegów gmina Dobra Szczecińska, choć ma statut gminy wiejskiej, zdecydowanie zmieniła swój charakter. Do połowy lat 90. ub. wieku dominowała działalność rolnicza, obecnie działalność handlowo-usługowa oraz mało uciążliwa działalność produkcyjna. Władze gminy prowadzą także starania by pozyskać nowych inwestorów. Wskutek podjętych działań tempo przyrostu podmiotów gospodarki narodowej zarejestrowanych na terenie gminy jest wyjątkowo dynamiczne. Jeżeli stan z roku 1995 przyjąć jako wyjściowy (884) to do 2015 roku przybyło 3084 podmiotów, a zatem można powiedzieć, że w ciągu 20 lat zwiększono liczbę podmiotów gospodarczych prawie 4,5 krotnie (tylko pomiędzy rokiem 2014 a 2013 zanotowano wzrost o 162 podmioty).

Gmina stała się również dobrym miejscem do życia młodych, zasobniejszych Szczecinian, którzy dbają jednocześnie o to, by tereny na których się osiedlili nie straciły walorów turystycznych. M. in. za namową mieszkańców wśród wydatków gminnych za lata 2009-2017 znalazły się takie projekty jak: budowa ścieżek rowerowych w gminie, zagospodarowanie terenu przy jeziorze w Stolcu, budowa międzygminnego schroniska dla zwierząt w Dobrej, zamontowanie oświetlenia solarnego na placach zabaw i na wybranych ulicach w gm. Dobra Szczecińska, a także budowa i zagospodarowanie terenów rekreacyjnych w Wąwelnicy, Bezrzeczu, Wołczkowie, Mierzynie, budowanie "orlików" i przebudowa istniejących boisk oraz zagospodarowanie użytku ekologicznego Ptasi Zakątek w Dołujach. Władze gminy wraz z mieszkańcami po-

\footnotetext{
${ }^{2}$ Władzom gm. Dobra Szczecińska przyznano pomoc w ramach
Programu Rozwoju Obszarów Wiejskich na lata 2007-2013 oś 3 „Jakość życia na obszarach wiejskich i różnicowanie gospodarki wiejskiej”, działanie 321 „Podstawowe usługi dla gospodarki wodnej i ludności wiejskiej”. Realizacja zadania inwestycyjnego pn. „Budowa i przebudowa oczyszczalni ścieków w m. Redlica, gm. Dobra Szczecińska było możliwe na mocy porozumienia pomiędzy Gminą a Samorządem Województwa Zachodniopomorskiego w Szczecinie.
} 
ones, and development of the ecological site of Ptasi Zakątek in Dołuje. The municipality authorities together with the inhabitants obtained funding from the EU for organising a Polish-German bicycle tour "Along Elizabeth's trail", the annual Polish-German "Rose Festival", erection of 2 bronze monuments of Countess Elizabeth von Arnim, a resident of these lands during the turn of XIX and XX centuries ${ }^{3}$. In addition, courtesy of local authorities through the area of the municipality runs an off-road rally route called "Baja Poland", in which many well-known competitors participate, including, among others, A. Małysz; it is also a way to promote the region and its values among lovers of extreme sports. Promotion, in terms of the local economy, is understood as "the propagation of the municipality, consisting in creating a positive, territorial or municipal image attracting potential customers by showcasing such values as: location, economic or natural values" [Strużycki 2006, p. 105].

Representatives of local authorities who are responsible for the socio-economic development of their region and, therefore, the authorities of the investigated LGU (local government unit) carry out well-informed promotional activities. Among the surveyed employees of Dobra Szczecińska Municipality ( $\mathrm{n}=20$ people), the most popular forms of promotion of the studied municipality were: running a website - 95\% of indications, participation in competitions about knowledge of a given region - $40 \%$, all sorts of publications (press, monographs, catalogue publications) - 50\%, but also organising tours (on foot and by bike) with a guide in cooperation with PTTK /Polish Tourist and Sightseeing Society/ and organising various events (national and international ones) in municipal venues. Figure 1 presents the activities undertaken in Dobra Szczecińska for its promotion. zyskały środki z funduszy unijnych na zorganizowanie polsko-niemieckiego rajdu rowerowego „Szlakiem Elizabeth”, corocznego polsko-niemieckiego „Festiwalu róż", wykonanie z brązu 2 pomników hrabiny Elizabeth von Arnim, mieszkanki tych ziem z przełomu XIX i XX wieku³. Ponadto przy uprzejmości władz lokalnych przez tereny gminy przebiega trasa rajdu samochodów terenowych pod nazwą „Baja Poland”, w której bierze udział wielu znanych zawodników, m.in. A. Małysz; jest to również sposób na promocję regionu i jego walorów wśród miłośników sportów ekstremalnych. Promocja, w ujęciu gospodarki lokalnej, jest bowiem rozumiana jako „propagowanie gminy, polegające na tworzeniu pozytywnego, przyciągającego potencjalnych klientów obrazu terytorialnego lub miejscowości poprzez ukazywanie takich walorów, jak: lokalizacja, wartości ekonomiczne czy przyrodnicze" [Strużycki 2006, s. 105].

Przedstawiciele władz lokalnych, którzy są odpowiedzialni za rozwój społeczno-gospodarczy swojego regionu, a zatem i władze badanej JST prowadzą świadoma działalność promocyjna. Spośród przepytanych pracowników Urzędu Gminy Dobra Szczecińska (n = 20 osób) wynika, że najpopularniejszymi formami promocji badanej gminy było prowadzenie strony internetowej - $95 \%$ wskazań, udział w konkursach o wiedzy z danego regionu - 40\%, wszelkiego rodzaju publikacje (prasa, monografie, wydawnictwa katalogowe) - $50 \%$, ale też organizowane wycieczek (pieszych i rowerowych) z przewodnikiem przy współpracy z PTTK oraz organizowanie różnorodnych eventów (krajowych i międzynarodowych) na terenie gminy. Na rysunku 1 przedstawiono działania podejmowane w Dobrej Szczecińskiej na rzecz jej promocji.

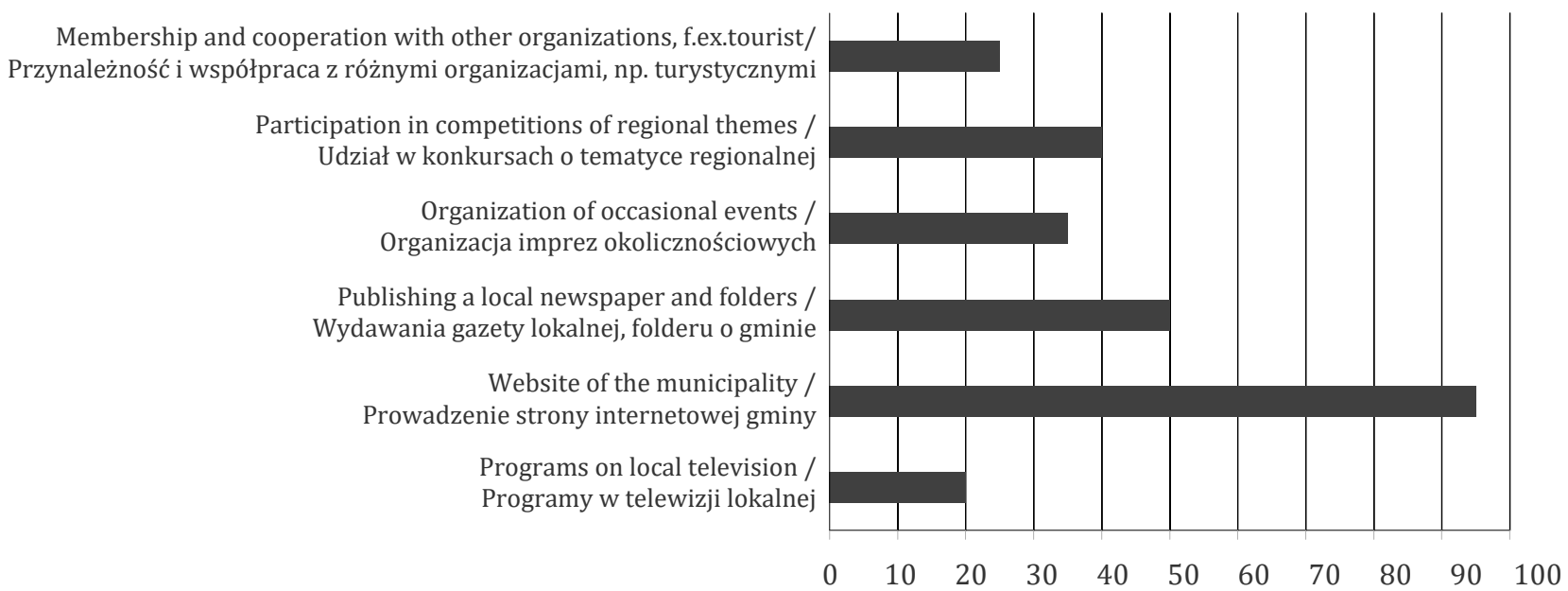

Figure 1. Activities undertaken in Dobra Szczecińska for its promotion

Rysunek 1. Działania podejmowane w Dobrej Szczecińskiej na rzecz jej promocji

Source: Author's own research.

Źródło: badania własne.

${ }^{3}$ Author's note: She was a countess, gardener and writer who lived and wrote books from 1896 to 1908, in present-day Rzędziany in Dobra Municipality. One of her books bears the title: Elizabeth and her garden (1898) included description of the beauty of an estate in Rzędziny.

\footnotetext{
Przypis autora: to hrabina, ogrodniczka i pisarka, która od 1896 do 1908 roku mieszkała i pisała książki w obecnych Rzędzianach, w gm. Dobra. Jedna z jej książek pt. Elizabeth i jej ogród z roku 1898 opisywała piękno majątku w Rzędzinach.
} 
Analysing the reports on the implementation of the budget for 2004 - 2017, only for promotional activities, the municipality spent a total of approximately 1480 000 PLN, while the expenditure for the promotion of the discussed LGU in particular years is shown in Figure 2.
Analizując sprawozdania z wykonania budżetu dot. lat 2004 - 2017 tylko na działalność promocyjną badana gmina wydała łącznie około 1480 tys. zł, natomiast jak kształtowały się wydatki na promocję omawianej JST w poszczególnych latach przedstawia rysunek 2.

Expenses (tys. PLN) / Wydatki (tys. zł)

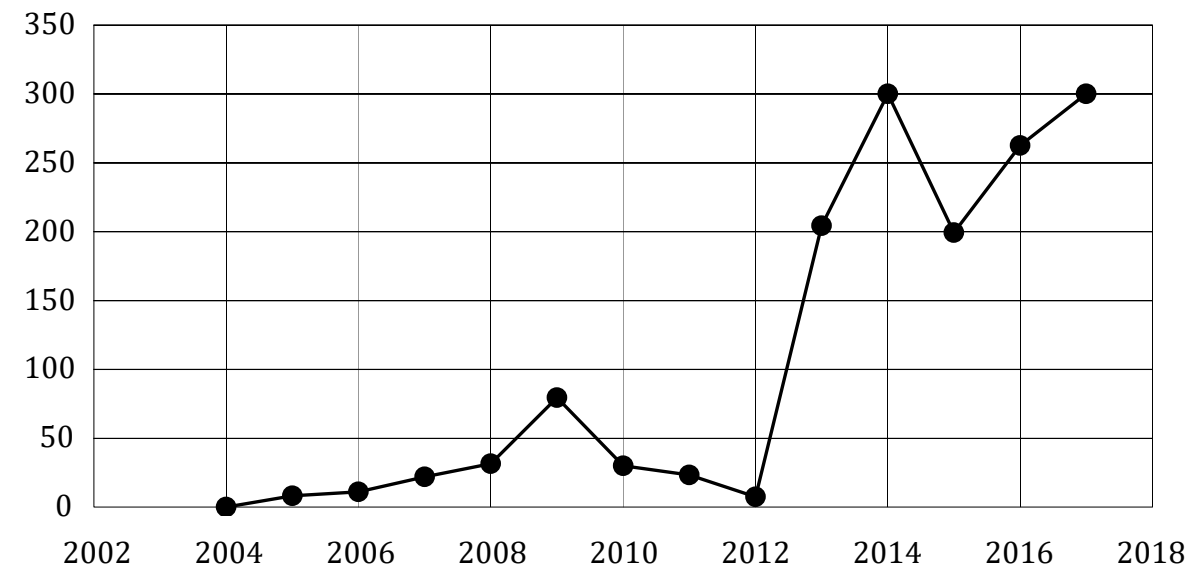

Figure 2. Expenditure for promotional activities in Dobra Szczecińska (in thousand PLN)

Rysunek 2. Wydatki na działania promocyjne w Dobrej Szczecińskiej(w tys. zł)

Source: Author's own research based on accounting documents of Dobra Municipality.

Źródło: badania własne na podstawie dokumentów rachunkowych Gminy Dobra.

The data presented in Figure 2 shows that in 2004 there was no item in the municipality's budget regarding promotional activities. The first significant expenditure on promotion was allocated in 2009 , and its effect was appreciated even later, at the end of 2012. Such a situation took place, because the promotion of sites/places is much more difficult than the promotion of consumer goods and produces measurable results with a significant time delay. Nevertheless, the authorities of the municipality appreciated the effects of marketing activities (including promotional ones) and since 2013 they have systematically allocated more than 200000 PLN to this type of activity.

The tasks with external orientation may include the comprehensive formation of the investment, tourist, cultural or commercial offer, effective communication with interested entities or shaping the personality, identity and attractive image of the area. The trademark of Dobra Szczecińska municipality is the logo presented in Figure. 3, which presents the word "dobra" in two meanings, namely Dobra Szczecińska is simply good (made possible by the fact that, coincidentally, the word "dobra" - part of the place name - means "good").
Z przedstawionych na rysunku 2 danych wynika, że w 2004 roku w ogóle nie było pozycji w budżecie gminy dot. działalności promocyjnej. Pierwsze znaczące wydatki na promocję przeznaczono dopiero w 2009 roku, a ich efekt został doceniony jeszcze później, bowiem pod koniec 2012 roku. Sytuacja taka miała miejsce, gdyż promocja terenów/miejsc jest znacznie trudniejsza aniżeli promocja dóbr np. konsumpcyjnych i przynosi mierzalne rezultaty ze znacznym opóźnieniem czasowym. Mimo to włodarze gminy docenili efekty działań marketingowych (w tym promocyjnych) i od 2013 roku systematycznie przeznaczają na ten rodzaj aktywności kwoty powyżej 200 tys. zł.

Do celów orientowanych na zewnątrz można zaliczyć kompleksowe kształtowanie oferty inwestycyjnej, turystycznej, kulturalnej czy handlowej, skuteczne komunikowanie się z zainteresowanymi podmiotami czy też kształtowanie osobowości, tożsamości i atrakcyjnego wizerunku danego obszaru. Znakiem rozpoznawczym gminy Dobra Szczecińska jest logo zaprezentowane na rys. 3, które słowo „dobra" ukazuje w dwóch znaczeniach, mianowicie Dobra Szczecińska jest po prostu dobra.

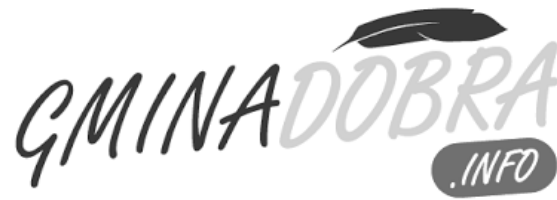

Figure 2. Logo of Dobra Szczecińska municipality on the information portal Rysunek 3. Logo gm. Dobra Szczecińska na portalu informacyjnym

Source: gminadobra.info.

Źródło: gminadobra.info. 
It is located on the website with information about the municipality (www.gminadobra.info), moreover, care was taken to ensure a comprehensive information flow to the residents and other people by printing the newspaper "Gazeta Gmina Dobra" as an addition to Tygodnik Policki and maintaining two more websites, like: Bezrzecze24.pl (www. bezrzecze24.pl) and GminaDobra24.pl (www. gminadobra24.pl/news.php). They contain, among others, information important for all internal and external stakeholders, from which it follows that Dobra Szczecińska municipality was ranked 23rd in the Ranking of Local Government Units with Sustainable Development (Ranking ... 2016). This is an exceptionally high position, as up to 1563 village municipalities were considered. The ranking was based on 15 indicators. First of all, the expenditure on investment projects per capita, number of working people per 1000 inhabitants, number of business entities per 1000 inhabitants, net migration rate, number of high school graduates per 1000 inhabitants and percentage of inhabitants using sewage treatment plants were taken into account. Placing information about achieving such a high position in the ranking was intended to show that the municipality is developing in accordance with the principles of balanced socioeconomic development and at the same time it was meant to popularise the municipality. Another way to promote the region is a brochure encouraging travellers and tourists to visit the described area entitled Wonderful and revealing (Wspaniała...2012). In addition, a video entitled "Dobra Municipality - Good Investment" (Municipality of Dobra 2014) was shot to promote the municipal area by showing the investments important to each community; their size and the scale of the facilities. In the film, one can view, among others a new primary school in Mierzyn, gymnasium in Bezrzecze, fire stations in Dobra and Wołczków, recreational areas in Mierzyn and Stolec, the Shelter for Homeless Animals and Vocational Development Centre in Dobra, as well as the bicycle path Buk - Łęgi and reconstructed border crossing Buk - Blankensee. In the bird's eye view, one can also admire the road Bezrzecze - Redlica and the nearby treatment plant.

Single campaigns or comprehensive marketing campaigns are primarily aimed at changing the awareness state of external and internal target groups, and also change their valuation and decisionmaking systems. As a result, new forms and directions of flow relocation between settlement units arise. Ultimately, the effect is such that decisions made by physical and legal entities in the municipality are wellinformed, there appears attachment to the region, responsibility for its development, conscious use of local values, decisions made with considrations for the needs of the immediate environment. It manifests itself in such activities as the inflow of new settlers and investors to Dobra Szczecińska municipality, joint creation of the municipality's future by establishing associations, foundations, and partnerships. For example, in 2008, the founding meeting of the Local Action Group Association "Dobre Gminy /Good
Jest ono umieszczone na stronie internetowej z informacjami o gminie (www.gminadobra.info), ponadto zadbano o szeroki przekaz wiadomości dla mieszkańców i innych osób drukując gazetę „Gazeta Gmina Dobra" jako dodatek do Tygodnika Polickiego oraz utrzymując kolejne dwa portale internetowe, jak: Bezrzecze24.pl (www.bezrzecze24.pl) oraz GminaDobra24.pl (www.gminadobra24.pl/news. php). W nich umieszczono między innymi informację ważną dla wszystkich interesariuszy wewnętrznych i zewnętrznych, z której wynika, że gm. Dobra Szczecińska zajęła 23 miejsce w Rankingu Jednostek Samorządu Terytorialnego Zrównoważonego Rozwoju (Ranking... 2016). Jest to wyjątkowo wysoka pozycja, bowiem brano pod uwagę aż 1563 gminy wiejskie. Ranking opracowywany był na podstawie 15 wskaźników. Pod uwagę brane były przede wszystkim wydatki na projekty inwestycyjne na mieszkańca, liczba osób pracujących na 1000 mieszkańców, liczba podmiotów gospodarczych na 1000 mieszkańców, saldo migracji, liczba absolwentów szkół ponadgimnazjalnych na 1000 mieszkańców oraz odsetek mieszkańców korzystających z oczyszczalni ścieków. Umieszczenie informacji o zajęciu tak wysokiego miejsca w rankingu miało pokazać, że gmina rozwija się zgodnie z zasadami zrównoważonego rozwoju społeczno -ekonomicznego i jednocześnie miało popularyzować gminę. Inny sposób promowania regionu to folder zachęcający podróżników i turystów do odwiedzania opisywanych terenów pt. Wspaniała i odkrywcza (Wspaniała...2012). Oprócz tego nagrano film zatytułowany „Gmina Dobra - dobra inwestycja” (Gmina Dobra 2014) promujący obszar gminy poprzez ukazanie ważnych dla każdej społeczności inwestycji, ich rozmiarów i skalę obiektów. Na filmie można zobaczyć m.in. nową szkołę podstawową w Mierzynie, salę gimnastyczną w Bezrzeczu, remizy strażackie w Dobrej i Wołczkowie, tereny rekreacyjne w Mierzynie i Stolcu, Schronisko dla Bezdomnych Zwierząt i Międzygminny Zakład Aktywności Zawodowej w Dobrej, a także ścieżkę rowerową Buk - Łęgi oraz przebudowane przejście graniczne Buk - Blankensee. Z dużej wysokości można też podziwiać drogę Bezrzecze - Redlica i położoną w pobliżu oczyszczalnię.

Pojedyncze akcje lub kompleksowe kampanie marketingowe mają przede wszystkim na celu zmianę stanu świadomości zewnętrznych i wewnętrznych grup docelowych, zmieniają także ich systemy wartościowania i podejmowania decyzji. W konsekwencji powstają nowe formy i kierunki przemieszczeń strumieni między jednostkami osadniczymi. Ostatecznie efekt jest taki, że decyzje podejmowane przez podmioty fizyczne i prawne na terenie gminy są świadome, następuje przywiązanie do regionu, odpowiedzialność za jego rozwój, świadome korzystanie z walorów lokalnych, decyzje podejmowane są z uwzględnieniem potrzeb najbliższego otoczenia. Przejawia sie to takimi działaniami jak napływ nowych osadników i inwestorów do gm. Dobra Szczecińska, współtworzenie przyszłości gminy poprzez zakładanie stowarzyszeń, fundacji, związków partnerskich. Na przykład w roku 2008 r. w Dołujach odbyło się zebranie założycielskie Stowarzyszenia 
Municipalities/" was held in Dołuje. The meeting was attended by representatives of the public, social and economic sectors from the areas of the following municipalities: Dobra Szczecińska, Kołbaskowo and Nowe Warpno, which implements Local Development Strategies (LDS). The Resolution No. 5 of 2015 (LDS 2015 , p. 7) shows that in 2009-2014 the Association:

- as part of measure 4.1/413 "Implementation of Local Development Strategies", announced competitions for the implementation of operations under the following ventures: "Creation and development of micro enterprises", "Diversification into non-agricultural activities", "Village renewal and development" and "Small projects". In 6 calls for proposals, a total of 81 applications were submitted, of which 37 received funding.

- as part of measure 4/4.31 "Operation of the local action group, skills acquisition and activation" supported activation activities that initiated the development of residents' interests and had an educational nature (organisation of workshops, classes and training). In total, 99 workshops were carried out.

In turn, in 2010-2014, as part of measure 4/4.21 "Implementation of cooperation projects", the Association and its partners implemented the following projects: "West Pomeranian Leader Games" (2010), "II West Pomeranian Leader Games" (2011), Leader Bike Rallies "Feeling one with your bike, grab a smile and hit the road" (2012), "Provincial Multi-trade Fair - Active Senior" (2013). In addition, the Association implemented 5 projects from the Human Capital Operational Program (HC OP) under the priority IX: Development of education and competences in the regions, measure 9.5. Grass-roots educational initiatives in rural areas.

The activities of the LAG Association Dobre Gminy so far, strengthened the local identity, integrated and activated the local community, and showed the validity of using EU funding for the development of rural areas.

The authorities of Dobra Szczecińska municipality not only focus on actions undertaken on a national scale, but also strive to talk about and write about the discusses unit outside Poland. For this purpose, representatives of this area started cooperation with partners from Germany and Italy. Together with them, they organise various events (including the Rose Festival or multi-ethnic meetings) and initiatives (the project "Europe for citizens"), which are reported by information sources in other countries (e.g. Italy, Germany, England or Hungary).

The marketing power of the municipality's impact is also influenced to a certain extent by a factor called synergistic reinforcement, which is the result of the imposition of various means of stimulating interested reference groups. The importance of a synergy effect in territorial marketing carried out by the municipality authorities consists of skilfully joining marketing ventures implemented by foreign entities and their groups and using them for their own purposes. An example would be the entry of
Lokalna Grupa Działania „Dobre Gminy”. W zebraniu uczestniczyli reprezentanci sektora publicznego, społecznego i gospodarczego z terenów gmin Dobra Szczecińska, Kołbaskowo i Nowe Warpno, które realizuje Lokalne Strategie Rozwoju (LSR). Z uchwały nr 5 z roku 2015 (LSR 2015, s.7) wynika, że Stowarzyszenie w latach 2009-2014:

- w ramach działania 4.1/413 „Wdrażanie Lokalnych Strategii Rozwoju” ogłaszało konkursy na realizację operacji $\mathrm{w}$ ramach przedsięwzięć: „Tworzenie i rozwój mikroprzedsiębiorstw”, „Różnicowanie w kierunku działalności nierolniczej”, „Odnowa i rozwój wsi” oraz 'Małe projekty". W 6 naborach złożono łącznie 81 wniosków, z czego dofinansowanie uzyskało 37.

- w ramach działania 4/4.31 „Funkcjonowanie lokalnej grupy działania, nabywanie umiejętności i aktywizacja" wspierało działania aktywizujące, które inicjowały rozwój zainteresowań mieszkańców oraz miały charakter edukacyjny (organizacja warsztatów, zajęć i szkoleń). Łącznie realizowano 99 warsztatów.

Z kolei w latach 2010-2014 w ramach działania 4/4.21 „Wdrażanie projektów współpracy Stowarzyszenie" wraz z partnerami zrealizowało następujące projekty: „Leaderowskie Igrzyska Zachodniopomorskiego" (2010), „II Leaderowskie Igrzyska Zachodniopomorskiego" (2011), Leaderowskie Zloty Rowerowe „Z rowerem za pan brat, bierz uśmiech i dawaj w świat” (2012), „Wojewódzkie Targi Wielobranżowe Aktywny Senior" (2013). Ponadto Stowarzyszenie zrealizowało 5 projektów z Programu Operacyjnego Kapitał Ludzki (PO KL) w ramach priorytetu IX Rozwój wykształcenia i kompetencji w regionach, działanie 9.5 Oddolne inicjatywy edukacyjne na obszarach wiejskich.

Dotychczasowa działalność Stowarzyszenia LGD Dobre Gminy wzmocniła lokalną tożsamość, zintegrowała i zaktywizowała lokalną społeczność, a także ukazała słuszność korzystania z dofinansowania ze środków unijnych na rzecz rozwoju obszarów wiejskich.

Władze gminy Dobra Szczecińska nie tylko skupiają się na działaniach podejmowanych na skalę krajową, ale także zabiegają o to, by o badanej jednostce mówiono i pisano także poza granicami Polski. W tym celu przedstawiciele terenu podjęli współpracę z partnerami z Niemiec i z Włoch. Razem z nimi organizują różne imprezy (m.in. festiwal róż, czy spotkania multietniczne) oraz inicjatywy (projekt „Europa dla obywateli”), o których wspominają źródła informacyjne w innych krajach (np. we Włoszech, Niemczech, Anglii czy Węgier).

Na marketingową siłę oddziaływania gminy wpływa w pewnej mierze także czynnik nazwany wzmocnieniem synergicznym, a będący efektem nałożenia się różnorodnych środków stymulowania zainteresowanych grup odniesienia. Znaczenie efektu synergicznego w marketingu terytorialnym prowadzonym przez władze gminy polegają na umiejętnym włączeniu się w przedsięwzięcia marketingowe realizowane przez podmioty obce i ich grupy, i wykorzystanie ich dla własnych celów. Przykładem może być wpisanie 
Dobra Szczecińska municipality to the Association of the Szczecin Metropolitan Area (ASMA). ASMA is an organisation based on solidarity cooperation between local governments and coordinating work aimed at creating a strong metropolitan center. Joint efforts consist in, among others, preparing the concept of management of the Szczecin Metropolitan Area, development strategy, introduction of legislative regulations, lobbying and other activities showcasing the investment, economic and cultural attractiveness of the area. Joint undertakings in the field of an integrated bicycle route system, an integrated communication system and an integrated network of transport routes, effective improvement of public services quality, determination and optimal use of tourist potential in cross-border regions, as well as the promotion and attention to cross-border tourist routes are considered to be particularly valuable.

Dobra Szczecińska municipality is particularly interested in piloting and participating in the construction of Szczecin ring road (the so-called Western Bypass of Szczecin), which on the one hand will divert some of the car traffic from crowded municipal roads, but at the same time will be an important artery for entrepreneurs who operate or will conduct investment activities in the area of Dobra Szczecińska municipality. The authorities of the discussed area are striving to ensure that the bypass project includes appropriate exit ramps in the direction of places that the municipality has allocated for investments or where the entrepreneurs already operate. The second argument for joining ASMA was to meet the residents' requests to improve bus service to/from Szczecin. The ASMA concept assumes that public transport will connect larger towns lying in Dobra Szczecińska Municipality directly with Szczecin. Then, for one ticket, residents of the studied unit will be able to travel both within the municipality and in the city of Szczecin. The West Pomeranian capital will also take care of the combination of cycle routes and tourist routes, so that they constitute a ready-made uniform product, which is recommended to visitors and residents of the surrounding area.

\section{Conclusions}

Territorial marketing is an important tool for building a strong position of a municipality in an increasingly competitive social environment. Among others, it is a very good tool to provide a clue about how to look for a "specialty" of a given municipality. In the case of Dobra Szczecińska Municipality, which, by law, constitutes a local government community and appropriate territory, the most important resources (specific features, discoveries) are people, culture and the natural environment. The task of the municipality authorities was to recognize this specificity and to base the marketing strategy on it, followed by proper use the knowledge gained during the process of brand building. Based on the analysis of numerous and extensive source documents, it can be stated that through the range of adopted strategies gm. Dobra Szczecińska do Stowarzyszenia Szczecińskiego Obszaru Metropolitalnego (SSOM). SSOM to organizacja bazująca na solidarnej współpracy samorządów i koordynująca prace zmierzające do stworzenia silnego ośrodka metropolitalnego. Wspólne prace polegają m.in.: na przygotowaniu koncepcji zarządzania Szczecińskim Obszarem Metropolitalnym, strategii rozwoju, wprowadzeniu uregulowań legislacyjnych, lobbingu i innych działaniach eksponujących atrakcyjność inwestycyjną, gospodarcza i kulturową obszaru. Za szczególnie cenne uważa się wspólne przedsięwzięcia w zakresie zintegrowanego systemu tras rowerowych, zintegrowanego systemu komunikacyjnego i zintegrowana sieć dróg transportowych, skutecznego podnoszenia jakości usług publicznych, określenia i optymalnego wykorzystania potencjału turystycznego transgranicznych regionów, a także rozpropagowanie transgranicznych szlaków turystycznych i opieka nad nimi.

Gminie Dobra Szczecińska szczególnie zależy na pilotowaniu i współudziale przy budowie obwodnicy miasta Szczecin (tzw. Zachodnie Obejście Szczecina), która $\mathrm{z}$ jednej strony odciągnie część ruchu samochodowego z zatłoczonych dróg gminnych, ale jednocześnie będzie ważną arterią dla przedsiębiorców, którzy działają lub będą prowadzić działania inwestycyjne na obszarze gm. Dobra Szczecińska. Władze omawianego terenu zabiegają o to, aby wpisano w projekt obwodnicy odpowiednie zjazdy w kierunku miejsc, które gmina przeznaczyła na inwestycje lub tam, gdzie przedsiębiorcy już działają. Drugim argumentem przemawiającym za przystąpieniem do SSOM było wyjście naprzeciw prośbom mieszkańców o usprawnienie komunikacji autobusowej w/z kierunku Szczecina. Koncepcja SSOM zakłada, że komunikacja miejska połączy większe miejscowości z gm. Dobra Szczecińska bezpośrednio ze Szczecinem. Wówczas na 1 bilet mieszkańcy badanej jednostki będą mogli jeździć i na terenie gminy i na terenie miasta Szczecin. Stolica województwa zachodniopomorskiego zadba też o połączenie szlaków rowerowych i tras turystycznych, aby stanowiły gotowy jednolity produkt, który polecany jest zwiedzającym i mieszkańcom okolic.

\section{Wnioski}

Marketing terytorialny jest istotnym narzędziem budowania silnej pozycji gminy $\mathrm{w}$ coraz bardziej konkurencyjnym środowisku społecznym. Między innymi jest on bardzo dobrym narzędziem podpowiadającym jak szukać „,specjalności” danej gminy. W przypadku gminy Dobra Szczecińska, którą zgodnie z ustawą tworzy wspólnota samorządową i odpowiednie terytorium, najważniejszymi zasobami (specyfikami, odkryciami) są ludzie, kultura i środowisko naturalne. Zadaniem władz gminnych było dostrzeżenie tej specyfiki i oparcie o nią strategii marketingowej. Następnie umiejętne wykorzystane zdobytej wiedzy przy budowie marki. Na podstawie analizy licznych i obszernych dokumentów źródłowych można stwierdzić, że poprzez wachlarz przyjętych strategii i podjętych działań udało się wykreować markę 
and implemented measures, it was possible to create the brand of this place. This brand represents a certain added value, which has a measurable impact on the competitive position and attractiveness of the discussed territory. Territorial marketing of Dobra Szczecińska Municipality has created a local brand that manifests itself on three levels as the identity, image and the brand of local products. Having a strong brand allows the municipality to achieve tangible benefits, such as an increase in attractiveness and competitiveness.

The currently investigated municipality is, as suggested by the municipality's logo, perceived as an exceptionally good area both for living and for running a business. This is proved by the high increase in the number of inhabitants and business entities. Also, the high score obtained by the municipality in the Local Government Units Ranking indicates that the land management is very good, well-informed and takes into account the needs of the current and future generations. On the other hand, the tasks set for the governing authorities of this area, such as:

- recognising the needs and residents' demand for specific products and their satisfaction;

- creating the image of the municipality - mainly on the basis of activities contributing to the quality of Dobra Szczecińska Municipality area, that is a skilful combination of the natural environment values with the necessity of developing settlement and economic activity,

- creating the municipality's products and effectively encouraging the purchase of products of Dobra Szczecińska Municipality through coordinated promotional activities,

are implemented on a regular basis. Efforts have been made so that anyone thinking about Dobra Szczecińska Municipality would spontaneously associate it with a set of positive impressions and interpretations. Care was also taken to provide reliable, clear and legible information about everything that happens in the municipality, and several platforms for discussions with the authorities of this area have been created, giving an example of how the authorities, residents and entrepreneurs can jointly set development paths for a given area. The image of an individual is inseparably connected the notion of identity which determines the image ofDobra Szczecińska Municipality in the minds of residents and other people. The identity of the municipality in question was defined as a set of characteristic features that distinguish it from others and express all activities that are undertaken, creating its specific individuation and character. Dobra Szczecińska Municipality is a place where mainly young people live, most often running their own business activities. The ranking also shows that it is a unit boasting the highest ratio of people with higher education in the region. Everyone in the municipality takes care of the spatial order, cultivating traditions and customs, discovering and respecting the culture associated with the site of current and former residents.

The research shows that the marketing activities of the municipality authorities have produced a positive miejsca. Marka ta stanowi pewną wartość dodaną, która ma wymierny wpływ na pozycję konkurencyjną i atrakcyjność omawianego terytorium. Marketing terytorialny gm. Dobra Szczecińska wykreował markę lokalną, która wyraża się trójpłaszczyznowo jako tożsamość, wizerunek i markę produktów lokalnych. Posiadanie silnej marki pozwala gminie osiągnać wymierne korzyści, jak podniesienie atrakcyjności i konkurencyjności.

Obecnie badana gmina jest - zgodnie z sugestią płynącą z loga gminy - postrzegana jako obszar wyjątkowo dobry zarówno do zamieszkania jak i prowadzenia działalności gospodarczej. Świadczy o tym wysoki przyrost liczby mieszkańców i podmiotów gospodarczych. Również wysoka nota zajęta przez gminę w Rankingu Jednostek Samorządu Terytorialnego Zrównoważonego Rozwoju jest świadectwem tego, że zarządzanie terenem jest bardzo dobre, świadome i uwzględnia potrzeby obecnych i przyszłych pokoleń. Natomiast zadania stawiane włodarzom terenu jak:

- poznanie potrzeb i popytu mieszkańców na określone produkty i ich zaspokajanie;

- wykreowanie wizerunku gminy - głównie na podstawie działań służących jakości przestrzeni gminy Dobra Szczecińska, czyli umiejętne połączenie walorów środowiska naturalnego z koniecznością rozwoju osadnictwa i działalności gospodarczej,

- wykreowanie produktów gminy i skuteczne zachęcanie do zakupu produktów gm. Dobra Szczecińska poprzez skoordynowaną działalność promocyjną,

są realizowane na bieżąco. Postarano się, by każdy myśląc o gminie Dobra Szczecińska spontanicznie łączył to z zestawem pozyty wnych wrażeń i interpretacji. Zadbano także o rzetelny, jasny i czytelny przekaz informacji o wszystkim co dzieje się na terenie gminy, stworzono kilka platform do dyskusji z władzami terenu, dając przykład jak władze wraz z mieszkańcami i przedsiębiorcami mogą razem wytyczać ścieżki rozwoju dla danego obszaru. Z wizerunkiem jednostki nierozerwalnie związane jest pojęcie tożsamości, która determinuje obraz gminy Dobra Szczecińska w świadomości mieszkańców i innych ludzi. Tożsamość omawianej gminy określona została jako zbiór cech charakterystycznych, które wyróżniają ją spośród innych i wyrażają się wszelkimi działaniami, jakie są podejmowane, tworząc jej swoistą osobowość i charakter. Gmina Dobra Szczecińska jest miejscem, w którym mieszkają przede wszystkim ludzie młodzi, prowadzący najczęściej własną działalność gospodarczą. Z Rankingu wynika jednocześnie, że jest to jednostka, która może poszczycić się najwyższą w regionie wartością współczynnika osób z wyższym wykształceniem. Wszyscy w gminie wspólnie dbają o ład przestrzenny, kultywowanie tradycji i obyczajów oraz odkrywają i szanują kulturę związaną z miejscem obecnych i dawnych mieszkańców.

$\mathrm{Z}$ przeprowadzonych badań wynika, że marketingowe działania władz gminy przyniosły pozytywny rezultat. Między innymi: walory terenu są rozpoznawalne i cenione $\mathrm{z}$ dala od jego granic, $\mathrm{np}$. 
result. Among others: the advantages of the land are recognisable and appreciated far from its borders, e.g. local residents on both Polish and German side know and willingly participate in Polish-German cycling rallies. They are admirers and buyers at the Festival of Roses, observers, and participants of the Off-Road Rally, "Baja Poland". The municipality is highly valued for the clean natural environment, nature attractions such as lakes, fields, forests, or ecological agricultural products from 2 ecological farms.

During the assessment of the management of Dobra Szczecińska Municipality using the marketing philosophy (accoriding to the definition adopted at the beginning of the discussion), it can be stated that it certainly leads to satisfying the needs and desires of the inhabitants and entrepreneurs who work there. It also leads to the improvement of the material conditions of life as well as the spiritual development of the local community. Dobra Szczecińska Municipality is identified as a municipality that has achieved success, which is why it is perceived very positively and highly valued. And yet, there are some drawbacks to such course of events, like, among others: difficult road everyday transportation between the municipality and Szczecin, increasingly higher land prices, constantly growing investment expenditures, etc.

\section{References / Literatura:}

1. Chrzan E. (2015), Marketing terytorialny w kontekście rozwoju zrównoważonego. Zeszyty Naukowe Politechniki Częstochowskiej, Zarządzanie Nr 20, s. 110-119.

2. Florek M. (2013), Podstawy marketingu terytorialnego. Wydawnictwo Uniwersytetu Ekonomicznego w Poznaniu, Poznań.

3. Komorowski J. (1993), Marketing miejski i jego znaczenie we współczesnym rozwoju miasta. Zeszy ty Naukowe AE w Poznaniu, Prace z zakresu gospodarki przestrzennej, ser. I, nr 206, s. 44-55.

4. Kożuch A. (2011), Rola samorządu terytorialnego we wspieraniu rozwoju lokalnego, W: A. Kożuch, A. Noworól (red.), Instrumenty zarządzania rozwojem $w$ przedsiębiorczych gminach. Monografie i Studia Instytutu Spraw Publicznych Uniwersytetu Jagiellońskiego, Kraków, s. 9-26.

5. LSR Stowarzyszeń LGD „Dobre Gminy”. Załącznik nr 1 do uchwały nr 5/2015 Walnego Zebrania Członków Stowarzyszenia Lokalna Grupa Działania „Dobre Gminy” z dnia 17.12.2015 r.

6. Marak J. (1994), Marketingowa strategia rozwoju gminy - koncepcja metodologiczna, W: J. Marak (red.) Zachowania podmiotów sfery konsumpcji (gospodarstw domowych, samorządów terytorialnych, przedsiębiorstw i instytucji). Akademia Ekonomiczna w Katowicach, Katowice, s. 169-171.

7. Moeller K., Rajala A. (2007), Rise of strategic nets - New modes of value creation. Industrial Marketing Management, No. 36 , s. 895-908. http://doi.org/10.1016/j.indmarman.2007.05.016.

8. Sekuła A. (2005), Marketing terytorialny, W: M. Daszkowska (red.) Marketing. Ujęcie systemowe. Wydawnictwo Politechniki Gdańskiej, Gdańsk, s. 216-237.

9. Siwa I. (2006), Turystyka jako forma aktywizacji gospodarczej w regionie - aspekt zarzadzania. Promotor, Warszawa.

10. Strużycki M. (2006), Przedsiębiorczość w procesach rozwoju rynków lokalnych. Instytut Rynku Wewnętrznego i Konsumpcji, Warszawa.

11. Szromnik A. (2011), Marketing terytorialny jako atrybut rynkowej orientacji miast oraz regionów, W: A. Grzegorczyk, A. Kochaniec (red.), Kreowanie wizerunku miast. Wyższa Szkoła Promocji, Warszawa, s. 18-41.

12. Szromnik A. (2012), Marketing terytorialny. Miasto i region na rynku. Wolters Kluwer, Warszawa.

\section{Websites/ Materiały internetowe:}

13. Bank Danych Lokalnych GUS, www.stat.gov.pl (data dostępu: 12.05.2017).

14. Diagnoza sytuacji społeczno-gospodarczej obszarów wiejskich województwa zachodniopomorskiego wraz z analizq SWOT. Raport końcowy (2013). CSRG, Szczecin, s. 35-36, http://zachodniopomorskie.ksow.pl/fileadmin/user_upload/zachodniopomorskie/pliki/Ekspertyza_Diagnoza_sytuacji_obszarow_wiejskich.pdf (data dostępu: 20.06.2017).

15. Gmina Dobra - dobra inwestycja (2014), http://www.gminadobra24.pl/print.php?news.1448, (data dostępu: 12.05.2017).

16. GminaDobra24.pl, http://www.gminadobra24.pl/news.php (data dostępu: 10.05.2017).

17. http://www.bip.dobraszczecinska.pl (data dostępu: 12.05.2017).

18. http://szczecin.stat.gov.pl/vademecum/vademecum_zachodniopomorskie/portrety_gmin/powiat_policki/gmina_wiejska_dobra_szczecinska.pdf (data dostępu: 12.05.2017). 
19. http://szczecin.stat.gov.pl/vademecum/vademecum_zachodniopomorskie/portret_obszaru_metropolitalnego/szczecinski_obszar_metropolitalny.pdf (data dostępu: 12.05.2017).

20. https://www.wup.pl/pl/dla-instytucji/statystyka-badania-i-analiza/bezrobocie-w-gminach (data dostępu: 10.05.2017).

21. Ranking Jednostek Samorzqdu Terytorialnego Zrównoważonego Rozwoju (2016), http://www.gminadobra24.pl/news. php?extend.3248.2 (data dostępu: 10.06.2017).

22. Wspaniała i odkrywcza (2012), Wyd. Gmina Dobra, https://www.slideshare.net/BiuroSSOM/folder-gminy-dobra, (data dostępu: 10.06.2017). 